\title{
Water management challenges at Mushandike irrigation scheme in Runde catchment, Zimbabwe
}

\author{
Jose A. Malanco ${ }^{1,2}$, Hodson Makurira ${ }^{1}$, Evans Kaseke ${ }^{3}$, and Webster Gumindoga ${ }^{1}$ \\ ${ }^{1}$ Department of Civil Engineering, University of Zimbabwe, P.O. Box MP167, Mt. Pleasant, Harare, Zimbabwe \\ ${ }^{2}$ National Directorate of Water, Ministry of Public Works and Housing, \\ P.O. Box 1613, Rua da Argelia 163, Maputo, Mozambique \\ ${ }^{3}$ Zambezi River Basin Commission, 128 Samora Machel Avenue, Harare, Zimbabwe \\ Correspondence: Webster Gumindoga (wgumindoga@gmail.com)
}

Received: 23 November 2017 - Revised: 11 February 2018 - Accepted: 14 February 2018 - Published: 29 May 2018

\begin{abstract}
Mushandike Irrigation Scheme, constructed in 1939, is located in Masvingo District and is one of the oldest irrigation schemes in Zimbabwe. Since 2002, the scheme has experienced severe water shortages resulting in poor crop yields. The low crop yields have led to loss of income to the smallholder farmers who constitute the irrigation scheme leading to water conflicts. The water stress at the scheme has been largely attributed to climate change and the uncontrolled expansion of the land under irrigation which is currently about 1000 ha against a design area of $613 \mathrm{ha}$. This study sought to determine the actual causes of water shortage at Mushandike Irrigation Scheme. Hydro-climatic data was analysed to establish if the Mushandike River system generates enough water to guarantee the calculated annual yield of the dam. Irrigation demands and efficiencies were compared against water availability and dam releases to establish if there is any deficit. The Spearman's Rank Correlation results of 0.196 for rainfall and 0.48 for evaporation confirmed positive but insignificant longterm changes in hydro-climatic conditions in the catchment. Water budgets established that the yield of the dam of $9.2 \times 10^{6} \mathrm{~m}^{3}$ year $^{-1}$ is sufficient to support the expanded area of 1000 ha provided in-field water management efficiencies are adopted. The study concludes that water shortages currently experienced at the scheme are a result of inefficient water management (e.g. over-abstraction from the dam beyond the firm yield, adoption of inefficient irrigation methods and high channel losses in the canal system) and are not related to hydro-climatic conditions. The study also sees no value in considering inter-basin water transfer to cushion the losses being experienced at the scheme.
\end{abstract}

\section{Introduction}

In most regions of the world, over $70 \%$ of freshwater is used for agriculture (World Bank, 2017). This figure can be as high as $85 \%$ in low and middle income countries where agriculture is the major economic activity (World Bank, 2006). By 2050, feeding a planet of 9 billion people will require an estimated $50 \%$ increase in agricultural production and a $15 \%$ increase in water withdrawals (World Bank, 2017).

In Africa, where agriculture is the backbone of most of the continent's economies, providing about $60 \%$ of all employment, huge investments in infrastructure for irrigation schemes over the last half century have been made, highlighting the importance of agriculture in food security for the growing population (Tafesse, 2003). Although the achievements of irrigation in ensuring food security and improving rural welfare have been impressive, experience also indicates problems and failures of irrigated agriculture (FAO, 2001; Cai et al., 2003). The poor performance of irrigation schemes are characterized by inefficient water use, unreliable water supply, degradation of irrigation infrastructure, lack of sound technical extension facilities and unconvincing farm management practices (Moyo et al., 2017; Malano and Burton, 2001). These will be compounded by uncertainties related to climate change (Nam et al., 2017). 


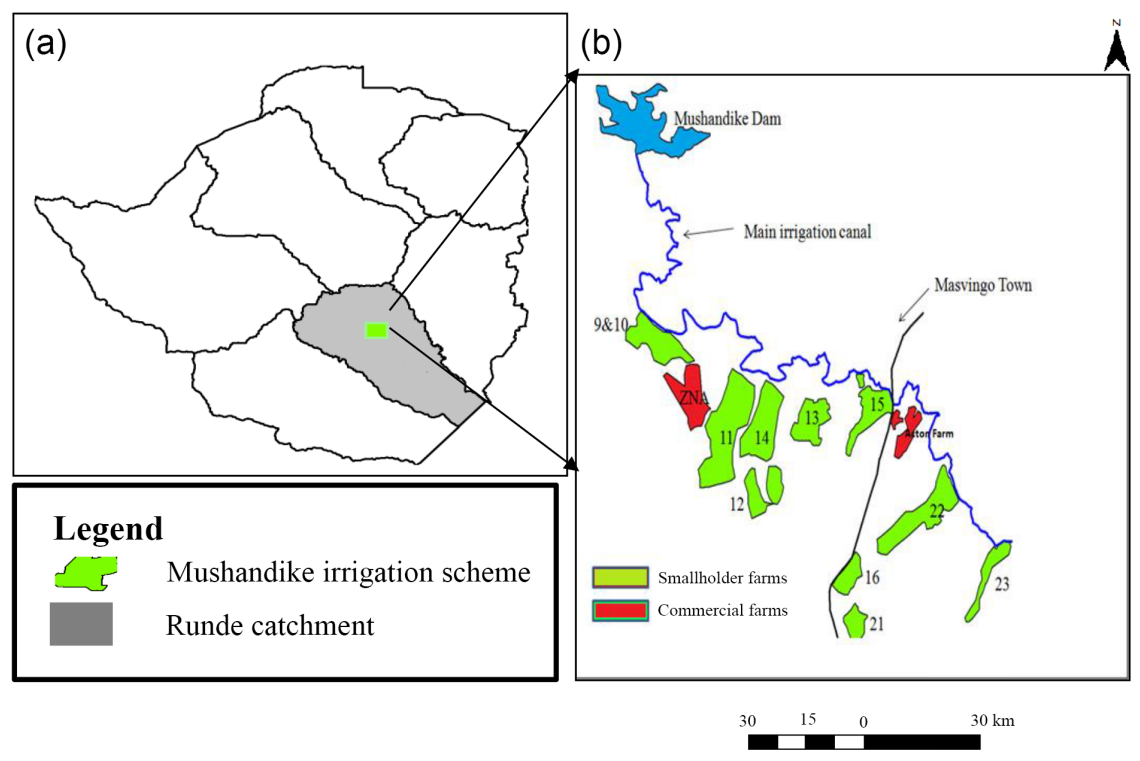

Figure 1. (a) Location of Mushandike Irrigation Scheme (b) Layout of Mushandike Irrigation Scheme.

In Zimbabwe, the total irrigated land dropped from 173513 ha to approximately 120000 ha primarily as a consequence of the land reform programme (Nhundu and Mushunje, 2010) and general economic challenges in the country. Efforts are being made to improve agricultural productivity in the communal lands through development and resuscitation of irrigation schemes where farmers can grow crops during both the wet and dry seasons (Makombe et al., 1998).

The Mushandike Irrigation Scheme, located $20 \mathrm{~km}$ south of Masvingo Town in Zimbabwe, is one of Zimbabwe's oldest communal irrigation schemes which provides livelihood income to the participating farmers and, also, is a source of fresh vegetables for the historical town of Masvingo. However, water shortages, blamed on low dam levels in the last 20 years have led to poor performance of the irrigation scheme resulting in food insecurity in the region and loss of livelihood income for the irrigation scheme participants (The Herald, 2017).

This study sought to confirm if the changes in the hydrological regime of the Mushandike Dam catchment have led to the serious water shortages that are attributed to the poor performance of the irrigation scheme.

\section{Material and methods}

\subsection{Study Area}

The study area is the Mushandike Irrigation Scheme, situated in the Tokwe sub-catchment within the Runde Catchment of Zimbabwe (Fig. 1). The climate is characterized by an unreliable rainfall season between November to April with the winter cropping season being experienced between May and
September. About $90 \%$ of the rainfall occurs during the period mid-November to early April. The average rainfall is $520 \mathrm{~mm}$ year $^{-1}$ with frequent and often extended dry spells during the season. The mean annual temperature is about $21^{\circ} \mathrm{C}$.

The catchment area upstream of Mushandike Dam is $319 \mathrm{~km}^{2}$ and the irrigation scheme lies immediately downstream of the dam. The scheme was established in 1939 to irrigate 613 ha (AGRITEX, 1989). The system flood irrigation methods with water being distributed through unlined canals. However, membership has increased and the area under irrigation has now expanded to 997 ha. At design stage, assumption of $1.5 \times 10^{3} \mathrm{~m}^{3} /$ ha/year was made as the annual irrigation demand. This is the general guideline used for the design of small-scale irrigation systems in Zimbabwe. With improvements in farming systems over time, this allocation is considered to promote inefficiency and, hence, there is room for increasing the area under irrigation if more efficient irrigation methods are adopted.

\subsection{Research approach}

\subsubsection{Analysis of rainfall and evaporation}

Annual rainfall, evaporation and temperature data was analysed using data recorded at two stations in Masvingo Town and at Mutirikwi Dam.

\subsubsection{Analysis of storage levels in the dam}

There is no streamflow measuring station upstream of the Mushandike Dam. However, there is data available on storage levels and releases from the dam. From this, a water balance at the dam could be conducted. 


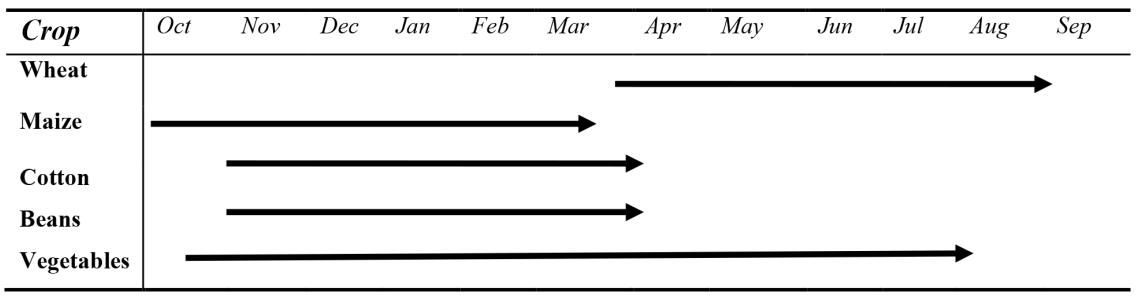

Figure 2. Typical cropping pattern and calendar at Mushandike Irrigation Scheme.

\subsubsection{Hydro-climatic trend analysis}

Monthly rainfall data from the Masvingo rainfall station between 1989 and 2016 was collected. The Spearman's rank correlation method was used to analyse the trends in the time series of hydro-climatic data collected. This analysis would show if there are any visible trends in rainfall amounts that may be causing reduced inflows into the dam. Similar analyses were conducted for temperature since crop water requirements are strongly related to prevailing temperature. The Spearman's correlation coefficient is calculated from Eq. (1):

$R_{\mathrm{sp}}=1-\frac{6 \sum D_{i}^{2}}{n\left(n^{2}-1\right)}$

Where, $R_{\mathrm{sp}}$ is the Spearman's Rank Correlation coefficient, $n$ is the length of data series, and $D_{i}$ is the difference between the rankings. A positive $R_{\mathrm{sp}}$ value indicates increasing trend while a negative value indicates decreasing trends in annual rainfall amounts received. A value of zero indicates no change in trends.

The precipitation variation from the mean was calculated using the Standardized Precipitation Index $\left(S_{\mathrm{pi}}\right)$ calculated using Eq. (2):

$S_{\mathrm{pi}}=\frac{P-P_{m}}{\delta}$

Where, $S_{\mathrm{pi}}$ is the standardized precipitation index, $P$ is the precipitation $\left(\mathrm{mm} \mathrm{year}^{-1}\right)$ in a given year; $P_{m}$ is average annual precipitation $\left(\mathrm{mm} \mathrm{year}^{-1}\right.$ ) and $\delta$ is the standard deviation.

The crop water requirements were estimated from the FAO pan evaporation method (FAO, 1992) as given by Eq. (3):

$\mathrm{ET}_{\mathrm{c}}=K_{\mathrm{c}} \cdot \mathrm{ET}_{o}$

where, $\mathrm{ET}_{\mathrm{c}}$ is crop water requirement $\left(\mathrm{mm} \mathrm{day}^{-1}\right) ; K_{\mathrm{c}}$ is crop coefficient (dimensionless); and $\mathrm{ET}_{o}$ is the reference crop evapotranspiration $\left(\mathrm{mm} \mathrm{day}^{-1}\right)$. The method was applied for maize (200 ha), beans (200 ha) and cotton (200 ha) which are grown as summer crops, wheat (600 ha) which is grown as a winter crop and vegetables ( $300 \mathrm{ha}$ ) which are grown throughout the year (Fig. 2).

Crop coefficients for each crop and for different growth stages were adopted from the FAO guidelines. Water requirements were calculated for each crop on a monthly basis.

\section{Results and discussion}

\subsection{Analysis of rainfall and evaporation}

Both the rainfall and evaporation patterns show an increasing visual trend (Fig. 2). Similar observations were made for temperature. The combination of both trends would naturally be linked to increased water demands for crops.

\subsection{Analysis of inflows and storage}

Since 1978, the storage levels do not show any period when the dam reached full supply capacity (FSC) (Fig. 5). However, the abstractions from the dam have been exceeding the design yield of $9.2 \times 10^{6} \mathrm{~m}^{3}$ year $^{-1}$ since 2006 . This is not recommended as it affects the reliability of water security in the long term.

\subsection{Hydro-climatic trends and analysis}

The Spearman's rank-correlation method, revealed weak positive rainfall and evaporation trends of 0.19 and 0.48 ), respectively. Both trends are insignificant, i.e. have $p \geq 0.05$. However, pronounced cyclic changes particularly for rainfall were observed which are characterised by longer dry periods and shorter wet periods (Fig. 6).

The annual irrigation water requirement calculated using the FAO crop water requirement estimation method for the expanded scheme of $997 \mathrm{ha}$ is $8 \times 10^{6} \mathrm{~m}^{3}$ year $^{-1}$ assuming the same cropping pattern is maintained over the years. The dam yield is $9.2 \times 10^{6} \mathrm{~m}^{3}$ year ${ }^{-1}$. The available water, based on the calculated firm yield, is, therefore, sufficient water to irrigate the expanded irrigation area.

\section{Discussion of findings}

The Mushandike Irrigation Scheme in Zimbabwe is experiencing serious water stress which has been attributed to increased area under irrigation and reduced water availability due to climate change. These are similar reasons advanced to explain underperformance of many small-scale irrigation schemes across the country. However, the study has established that the hydroclimatic conditions in the Mushandike Dam catchment have not changed significantly. The water 

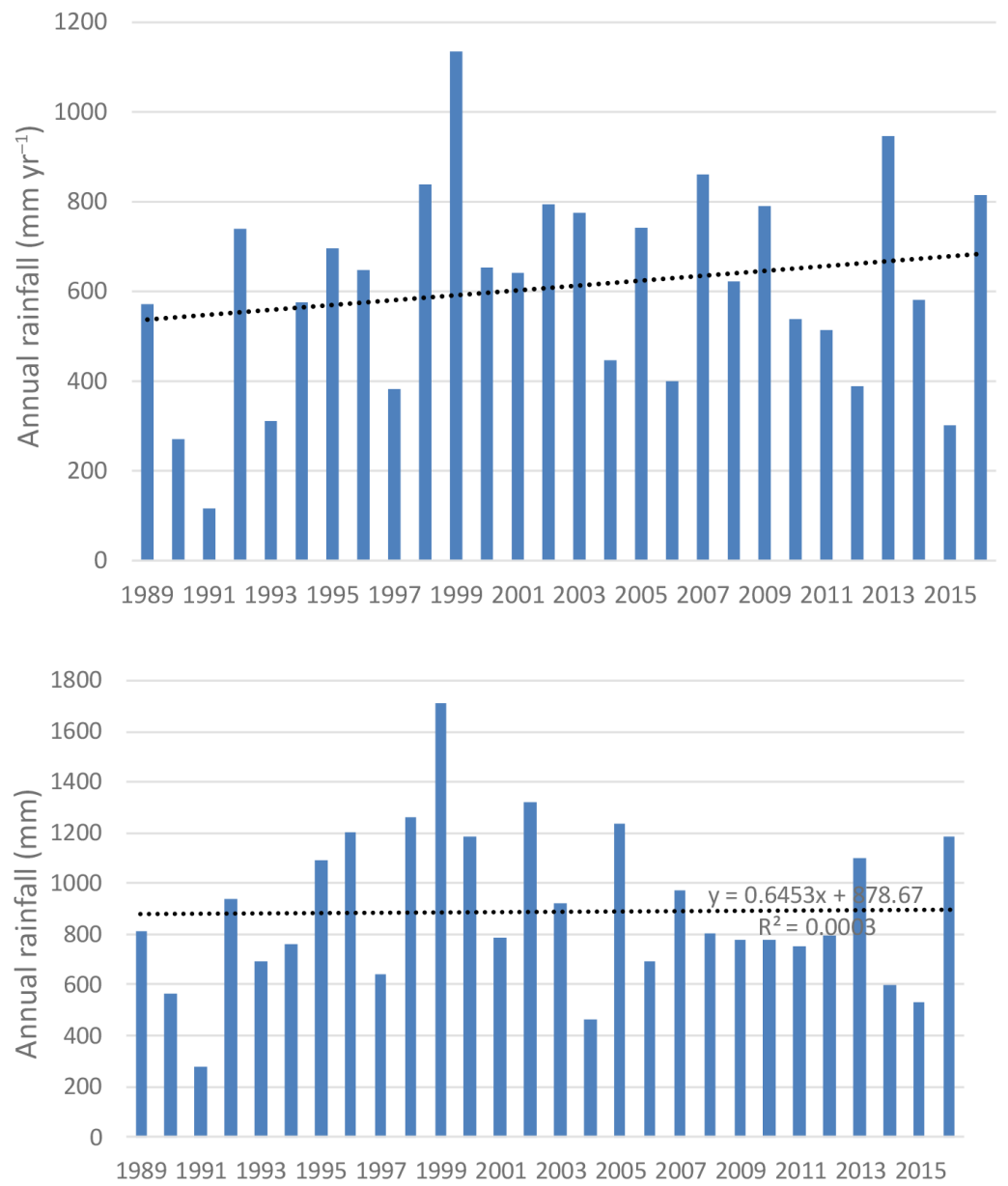

Dam data Linear (Dam data)

Figure 3. Rainfall trends at Mushandike Irrigation Scheme.

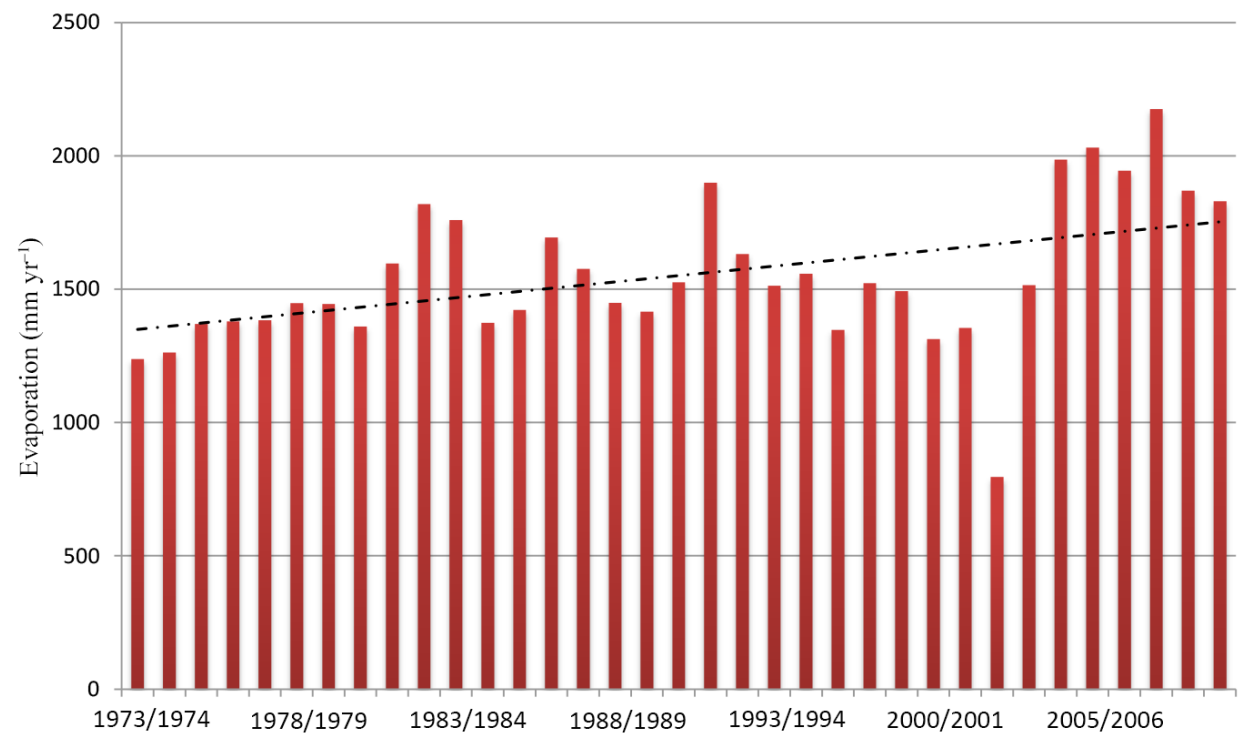

Figure 4. Evaporation trends at Mushandike Irrigation Scheme. 


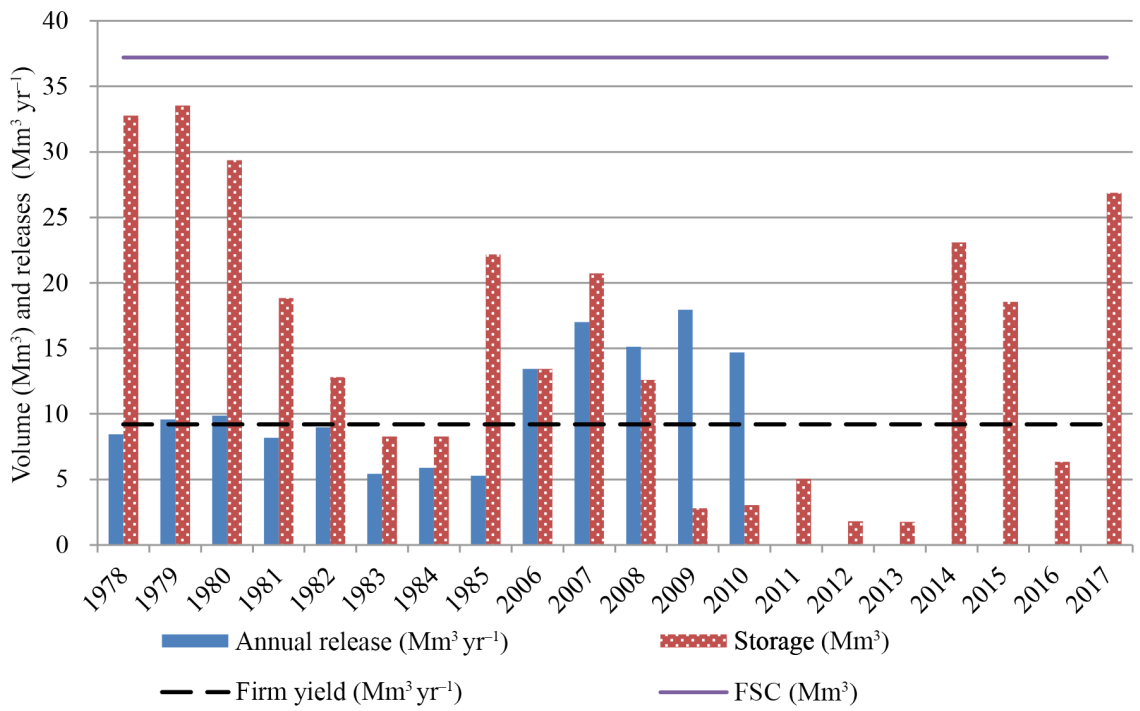

Figure 5. Storage levels in Mushandike Dam.

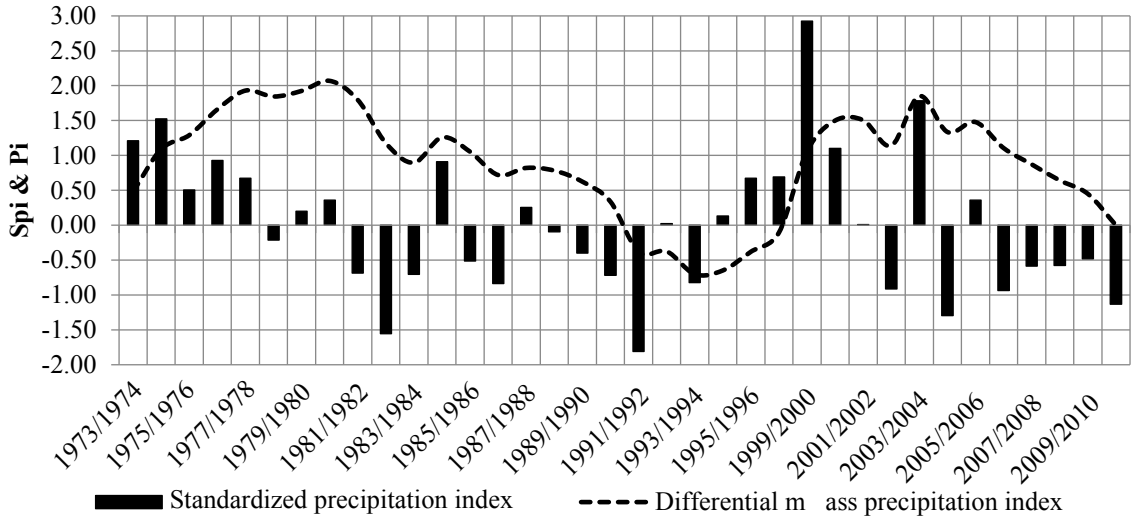

Figure 6. Cyclic changes on observed Rainfall (1974-2011).

stress at the irrigation scheme can only be attributed to infield water application inefficiencies in the irrigation scheme itself. Flood irrigation methods are not efficient. The situation is worsened by high transmission losses in the distribution system which comprise of unlined canals. The crop water requirements for the typical crops grown in the scheme have been estimated to be $8 \times 10^{3} \mathrm{~m}^{3} / \mathrm{ha} /$ year yet the desgn of the scheme assumed allocations of $15 \times 10^{3} \mathrm{~m}^{3} /$ ha/year. This has nurtured a culture of inefficiencies amongst the users and operators. Irrigation design guidelines for Zimbabwe should be adjusted to acknowledge improved irrigation and general farming methods and the increasing value of water that is associated with increased competition and uncertainties in climate conditions.

The serious water shortages at the scheme started during the period when annual abstractions started to exceed the design yield of the dam. This also suggests that the operation rules for the dam were violated in recent years. This, obvi- ously, leads to increased insecurity of supply from the dam on a long-term basis.

Accommodating the 997 ha of irrigation land using the generous allowance of $15 \times 10^{3} \mathrm{~m}^{3} / \mathrm{ha} /$ year would generate a deficit of $7 \mathrm{Mm}^{3}$ year ${ }^{-1}$. This water could be divered from a different catchment through inter-basin transfer. Technically, it would be possible as the adjacent Tokwe River system records good flows on an annual basis. However, this strategy would likely generate upstream-downstream conflicts in addition to being interpreted as promoting inefficient water use.

\section{Conclusions}

The water shortages at Mushandike Irrigation Scheme are caused by infield inefficiencies and not by the hydrology of the upstream catchment. The original irrigation design assumed a water allocation of $15 \times 10^{3} \mathrm{~m}^{3} / \mathrm{ha} /$ year which, in 
itself, is more than generous and promotes inefficient use of scare water resources. Inter-basin water transfer, while it is an option, cannot be promoted now as such intervention would be interpreted as promoting inefficient water use. Operation rules for the dam, which are related to the inflow patterns and the design yield of the dam should be respected at all times. Over-abstraction from the dam leads to long term water shortage. The problem of water stress at the scheme can be solved by improving water allocations and minimising infield losses without necessarily considering inter-basin water transfers.

Data availability. Data are not publicly accessible due to restrictions imposed by the supplier of the data.

Competing interests. The authors declare that they have no conflict of interest.

Special issue statement. This article is part of the special issue "Understanding spatio-temporal variability of water resources and the implications for IWRM in semi-arid eastern and southern Africa”. It is a result of the IAHS Scientific Assembly 2017, Port Elizabeth, South Africa, 10-14 July 2017.

Acknowledgements. The authors greatly appreciate WaterNet Phase 3 for funding this research.

Edited by: Christophe Cudennec

Reviewed by: Hubert H. G. Savenije and one anonymous referee

\section{References}

AGRITEX: Mushandike resettlement scheme project report update, Ministry of Lands, agriculture and rural resettlement, Harare, Zimbabwe, 1989.

Cai, X., McKinney, D. C., and Rosegrant, M. W.: Sustainability analysis for irrigation water management in the Aral Sea region, Agr. Syst., 76, 1043-1066, 2003.
FAO: Irrigation Water Management, Training Manual No. 7, FAO, Land and Water Development Division, Rome, Italy, 1992.

FAO: Smallholder irrigation technology: Prospects for Sub-saharian Africa, International Programme for Technology and Research in Irrigation and Drainage Knowledge Synthesis Report No. 3, March 2001, Melvyn Kay FAO/IPTRID Consultant IPTRID Secretariat Food and Agriculture Organization of the United Nations Rome, 2001.

The Herald: available at: http://www.herald.co.zw/ mushandike-irrigation-scheme-under-threat/, last access: 26 October 2017.

Makombe, G., Makadho, J. M., and Sampath, R. K.: An analysis of the water management performance of small holder irrigation schemes in Zimbabwe, Irrigation and Drainage Systems, 22, 253-263, 1998.

Malano, H. and Burton, M.: Guidelines for benchmarking performance in the irrigation and drainage sector, Food and Agriculture Organization of the United Nations, Rome, 2001.

Moyo, M., van Rooyen, A., Moyo, M., Chivenge, P., and Bjornlund, H.: Irrigation development in Zimbabwe: Understanding productivity barriers and opportunities at Mkoba and Silalatshani irrigation schemes, Int. J. Water Resour. D., 33, 740-754, https://doi.org/10.1080/07900627.2016.1175339, 2017.

Nam, W., Kim, T., Hong, E., and Choi, J.: Regional Climate Change Impacts on Irrigation Vulnerable Season Shifts in Agricultural Water Availability for South Korea, Water, 9, 735, https://doi.org/10.3390/w9100735, 2017.

Nhundu, K. and Mushunje, A.: Analysis of irrigation development post fast track land reform programme, A case study of Goromonzi District, Mashonaland East Province, Zimbabwe, A Poster presented at the Joint 3rd African Association of Agricultural Economists (AAAE) and 48th Agricultural Economists Association of South Africa (AEASA) Conference, Cape Town, South Africa, 19-23 September 2010.

Tafesse, M.: Small-scale irrigation for food security in sub- Saharan Africa, The ACP-EU Technical Centre for Agricultural and Rural Cooperation (CTA), Ethiopia, 2003.

World Bank: Reengaging in Agricultural Water Management, Challenges and Options, The World Bank Washington, DC, 2006.

World Bank: available at: https://blogs.worldbank.org/opendata/ chart-globally-70-freshwater-used-agriculture (last access: 3 March 2018), 2017. 